\title{
PRIOR COMPLAINT EVIDENCE UNDER THE EVIDENCE ACT 2006: THE SUPREME COURT JURISPRUDENCE
}

\author{
Holly Hill ${ }^{*}$
}

\begin{abstract}
At the time of writing, the Evidence Act 2006 has been in force for almost five years, but in several respects it has failed to fulfil its mandate of clarifying and simplifying New Zealand's rules of evidence. One area where this failure can be seen as most evident is in respect of evidence of prior complaints of sexual offending. Here, the rule governing previous consistent statements in s 35(2) of the Act radically changes the previous common law position, enacting entirely unfamiliar technical requirements in its place. This article provides thorough analysis of the problems with s 35(2) through an analysis of cases where the Supreme Court has struggled to interpret and apply the provision. Ultimately the article suggests that a less technical reform will provide the necessary simplicity and certainty that is currently absent from the provision.
\end{abstract}

\section{INTRODUCTION}

In 1989 the New Zealand Law Commission began researching avenues for reform of New Zealand's outdated and disorganised statutory rules of evidence. Its aim was to produce a body of "clear, simple and accessible" rules to clarify the confusion surrounding the common law, the Evidence Act 1908, and various statutory amendments. ${ }^{1}$ The product of the Commission's research and subsequent recommendations is today found in the Evidence Act 2006 (the Act). A significant and problematic change arising from the Act is the creation of a new rule in s 35 relating to the admissibility of evidence of a witness's previous statement that is consistent with their testimony.

The Act does not alter the common law position that evidence of a prior consistent statement is generally inadmissible (known at common law as the "rule against the narrative"). ${ }^{2}$ Instead, it enacts

* This paper was submitted as part of the LLB(Hons) programme at Victoria University of Wellington. I would like to thank my supervisor, Associate Professor Elisabeth McDonald, for her assistance and continuing support.

1 Law Commission Evidence: Reform of the Law (NZLC R55, 1999) at xviii.

2 DL Mathieson (ed) Cross on Evidence (online looseleaf ed, LexisNexis) at EVA35.4. 
two exclusive exceptions to the rule that are fundamentally different to the exceptions used at common law. In particular, the exception enacted in s 35(2) creates an entirely new process for the admission of such evidence: a witness's previous consistent statement can now only be admitted under s 35(2) if it responds to a relevant "challenge". This is fundamentally different from the common law "recent complaint" exception, under which evidence of a prior complaint in a sexual offence case made at the first reasonable opportunity was, in general, automatically admissible. ${ }^{3}$

This paper discusses the relevant components, policies and problems of s 35, with particular focus on evidence of prior complaint in cases that the Act terms "sexual cases". ${ }^{4}$ Some of the difficulties raised by s 35 include the meaning of "statement" under s 4 of the Act and, in particular, whether evidence of a prior complaint without substance meets this definition such that it falls within the previous consistent statement rule in the first place. The introduction of the new concept of a "challenge" to the exception to the exclusionary rule has also required explanation. Perhaps more important however, is the complex procedural difficulty necessitated by the "challenge" as a precondition to offering evidence of a prior consistent statement under s 35(2). It is the concept of a "challenge", but specifically when it will be triggered, that has concerned the Supreme Court in a number of recent cases which are the primary focus of this paper.

This article first examines the elements of the exclusionary rule as contained in s 35(1). I will then turn to the exception to the rule that is of relevance to evidence of prior complaints as contained in s 35(2). I will explain the nature of the new requirement of a challenge and its practical triggers, in conjunction with the requirement that evidence be admitted only in response to the challenge. I will look at the different ways in which the Supreme Court has tried to work around the technicalities of s 35(2) in the case of Rongonui $v R,{ }^{5}$ where a majority of the Court considered that a relevant challenge may be triggered at a pre-trial stage. I consider the implications of the decision in Rongonui and the ways in which the decision has been adopted in subsequent Supreme Court cases at different stages of the trial process.

This paper argues that, whilst creating a welcome codification of the common law 'rule against the narrative', the difficult requirement of a challenge and when it will be triggered has produced a body of case law that is anything but clear, principled and accessible. With the Law Commission's review of the Act to be completed in February 2013, ${ }^{6}$ I submit that a reform option proposed by the Ministry of Justice is an appropriate alternative to the current law, presenting a simpler statutory

3 Richard Mahoney and others The Evidence Act 2006: Act and Analysis (2nd ed, Brookers, Wellington, 2010) at EV35.04(1)

4 Evidence Act 2006, s 4, "sexual case".

5 Rongonui v R [2010] NZSC 92, [2011] 1 NZLR 23.

6 Section 202; New Zealand Law Commission "Commencement of Law Commission's Review of the Evidence Act 2006" (press release, 23 April 2012). 
reform. It is consistent with the principles and purpose of the Act to do away with the complicated statutory provision in its present state; and to prevent contradictory precedents arising from appellate courts. ${ }^{7}$

\section{SECTION 35(1): THE EXCLUSIONARY RULE}

Section 35(1) of the Evidence Act 2006 enacts the rule against the general admissibility of previous consistent statements. The section essentially codifies the common law 'rule against the narrative', except in terms of the purpose for which the evidence can be used: evidence admitted under either of the exceptions to s 35 can be used to prove its truth, and is not limited to simply proving consistency. ${ }^{8}$ A previous consistent statement means a "statement made by a witness at any time other than at the hearing at which the witness is giving evidence" ${ }^{9}$ that is consistent with the witness's evidence. ${ }^{10}$

The exclusionary rule in s 35(1) is most frequently at issue in sexual cases, commonly concerning the admissibility of a statement made by a victim to his or her friends or family before reporting the crime to the police. At common law, evidence of a sexual assault victim's prior complaint made at the first reasonable opportunity formed the basis of an exception to the rule against previous consistent statements and was automatically admissible, primarily through the complainant's evidence in chief, or through calling the person to whom the complaint was made as a witness (otherwise known as the "recent complaint" exception). ${ }^{11}$ It is clear that the "recent complaint" exception is not codified in the Act. While the Act does not bar the type of evidence contained in a recent complaint, ${ }^{12} \mathrm{~s} 35(2)$ creates an additional requirement to its admissibility by way of a prior challenge to the witness's veracity or accuracy, meaning it will no longer typically be admissible during the witness's evidence in chief. ${ }^{13}$ Thus it has been suggested that the new configuration of the rule enables the defence to pursue a tactic that "deliberately avoids" opening the door to a prior consistent statement. ${ }^{14}$

7 Section 6 .

$8 \quad$ Hart $v R$ [2010] NZSC 91, [2011] 1 NZLR 1 at [54].

9 Section 4, "previous statement".

10 Section 35(1).

11 See $R$ v Nazif [1987] 2 NZLR 122 (CA); Mahoney and others The Evidence Act 2006: Act and Analysis, above $\mathrm{n}$ 3, at EV35.04(1).

12 Contrast $R$ v Barlien [2008] NZCA 180, [2009] 1 NZLR 170 at [69].

13 Rongonui $v R$, above $\mathrm{n}$ 5, at [43].

14 "Briefing to the Hon Simon Power, Minister of Justice: Meeting with the Rt Hon Mr E W Thomas" (3 July 2009) IPC 0401 at 4 (Obtained under Official Information Act 1982 Request to the Ministry of Justice). See below in this paper section A, The Nature of the Required Challenge. 
A difficult feature of s 35(1) is that contained in the definition of "statement" in s 4:

(a) a spoken or written assertion by a person of any matter; or

(b) non-verbal conduct of a person that is intended by that person as an assertion of any matter.

"Assertion" is not defined in the Act. The term has since been interpreted to be limited to evidence where there is an intention to "make a statement, or assert a fact or opinion". ${ }^{15}$ Thus where the alleged assertion is merely an inference to be drawn from the evidence (an implied assertion), ${ }^{16}$ the evidence falls outside of the definition of statement and its admissibility will turn solely on considerations of relevance (s 7) and unfairly prejudicial effect (s 8). ${ }^{17}$ An irresistible inference, however, being one that the jury is bound to draw, can be indicative of an intention to assert. ${ }^{18}$

Also without definition under the Act, "consistent" is now settled to mean more than a "lack of inconsistency", ${ }^{19}$ but a positive reproduction of an element or the general tenor of the witness's testimony. ${ }^{20}$ Whether or not a previous statement is "consistent with the witness's evidence" 21 cannot properly be ascertained before the witness testifies. ${ }^{22}$ In the event that evidence of a previous statement is offered prior to the maker of the statement testifying, it must be considered a hearsay statement until the maker takes the stand, at which point consistency between the evidence will become apparent. ${ }^{23}$ This is despite the evidence not properly fitting within either of the two bases in s 18(1)(b) of the Act for offering hearsay evidence: because the witness will later testify, he or she is neither unavailable as a witness, nor set to cause undue expense or delay to the proceedings.

As summarised by the Law Commission, the rationale behind excluding prior consistent statements is "to prevent the parties from inundating the courts with voluminous amounts of repetitive material in order to shore up a witness's consistency". ${ }^{24}$ Repetitious evidence is an

15 R v Holtham [2008] 2 NZLR 758 (HC) at [44].

16 Hitchinson $v R$ [2010] NZCA 388 at [34].

$17 R v$ Holtham, above $\mathrm{n} 16$, at [53].

18 Rongonui $v$ R, above n 5, at [36]; Mahoney and others The Evidence Act 2006: Act and Analysis, above $\mathrm{n} 3$, at EV35.03(1); but see O'Donnell v R [2010] NZCA 352 at [38].

19 Law Commission Evidence: Evidence Code and Commentary (NZLC R55, 1999) at 99.

20 Hitchinson $v$ R, above $\mathrm{n}$ 17, at [26]; Hart $v$ R, above $\mathrm{n} 8$, at [10].

21 Section 35(1).

22 Mahoney and others The Evidence Act 2006: Act and Analysis, above n 3, at EV35.01(2).

23 Contrast Richard Mahoney "A Witness's Previous Statements: The Supreme Court Ushers in a New Era" (seminar paper presented in New Zealand Law Society "Criminal Law Symposium", 26 November 2010) at 4.

24 Law Commission Evidence: Evidence Code and Commentary, above n 20, at 99. 
inefficient use of the court's time, extending trials without placing new relevant material before the fact-finder. ${ }^{25}$ Instead, it has the effect of potentially making a witness and his or her testimony look more consistent, and therefore more credible and reliable. Implicit in a party calling a witness to testify is an endorsement of the credibility and reliability of the witness's evidence. ${ }^{26}$ The use of a prior consistent statement to further enhance these qualities at this stage is therefore unnecessary. Added to the concern that the witness's credibility may be unnecessarily enhanced by the evidence is the ease with which prior consistent statements can be fabricated for use at trial, thus unreliably enhancing credibility. ${ }^{27}$ Under the Act however, considerations of fabrication and reliability are better assessed when considering the weight to be given to the evidence under s 8 , and not its admissibility. ${ }^{28}$

The Act sets out two statutory exceptions to the exclusionary rule, though analysis of the exception contained in s 35(3) is beyond the scope of this paper. Section 35(2) introduces the exception to the rule that is based on the complicated and unfamiliar requirement of a challenge to the witness's evidence as a pre-condition to offering evidence of his or her prior consistent statement.

\section{SECTION 35(2): THE PROBLEMATIC EXCEPTION TO THE RULE}

Section 35(2) provides the statutory exception to the rule contained in s 35(1): ${ }^{29}$

A previous statement of a witness that is consistent with the witness's evidence is admissible to the extent that the statement is necessary to respond to a challenge to the witness's veracity or accuracy, based on a previous inconsistent statement of the witness or on a claim of recent invention on the part of the witness.

The aim and effect of a challenge to veracity (truthfulness) or accuracy is an attack on the consistency, and therefore the credibility and reliability, of a witness's testimony. Thus, in the circumstances dealt with by s 35(2), the rationale for exclusion of a prior consistent statement falls away: it is no longer repetitious or superfluous, but gains relevance beyond the content of what is said in an attempt to reaffirm the credibility and reliability of the witness's testimony. This important exception ensures that the requirement of promoting fairness to parties and witnesses is fulfilled: ${ }^{30}$

25 Grant Burston and Saeeda Verrall "Questioning of Witnesses" (seminar paper presented in New Zealand Law Society Intensive "Evidence Act 2006", June 2007).

26 DL Mathieson (ed) Cross on Evidence, above n 2, at EVA35.4.

27 Ibid.

28 See Rongonui $v$ R, above $\mathrm{n}$ 5, at [8].

29 Section 35(2).

30 Section 6(c). 
on the one hand, the party calling the witness is granted an avenue through which to admit evidence relevant to their case; on the other hand the witness is spared from feeling a loss of control, which could risk exacerbating an already limited understanding of the nature of the trial process and the role which the evidence plays. ${ }^{31}$ It is the limitations on the nature and requirements of a challenge, coupled with the standard of "extent necessary to respond" that ensures the exclusion of evidence that does not serve this purpose.

\section{A The Nature of the Required Challenge}

Whilst the nature of a challenge is said to be "general",32 it must be remembered that not every challenge to a witness's evidence will open the door to the admission of evidence of a prior consistent statement. ${ }^{33}$ The two technical prerequisites of s 35(2) must first be met: the challenge must be to either veracity or accuracy and it must be based on a previous inconsistent statement or claim of recent invention.

Instead, the nature of a challenge can be said to be "general" in the way that it is conveyed. A challenge does not hinge on technical or explicit wording, ${ }^{34}$ but can be inferred from the general theme and overall effect of the defence case, ${ }^{35}$ as assessed on the facts of the particular case. ${ }^{36}$ Factors relevant to the finding of a general challenge may include the length of the crossexamination, ${ }^{37}$ and the extent to which the witness's evidence is being contradicted. ${ }^{38}$ Where the case is before a jury this general, contextual assessment must be undertaken by the judge from the perception of the jury members, as they are in the position of finders of fact. ${ }^{39}$ It is therefore appropriate that the approach to identifying a challenge be general, as the jury could not be expected to understand the technicalities of a more complex, legalistic test. ${ }^{40}$

On the face of it, the contextual approach creates a broad area of uncertainty for defence counsel when contemplating the tone and nuances of the defence strategy. A certain line of cross-

31 Donna Buckingham, Elisabeth McDonald and Yvette Tinsley "Submission on the Evidence Bill 2005" at 11.

32 Stewart $v$ R [2008] NZCA 429, [2010] 1 NZLR 197 at [76]-[78].

33 Hart $v$, above $\mathrm{n} 8$, at [38].

$34 S \vee R$ [2008] NZCA 152 at [16].

35 Stewart $v$ R, above $\mathrm{n} 33$, at [82]; Hart $v$ R, above $\mathrm{n}$ 8, at [58].

$36 R v B$ [2010] NZSC 160, [2011] 2 NZLR 82 at [12].

37 Stewart $v$ R, above $\mathrm{n} 33$, at [71].

38 Mahoney and others The Evidence Act 2006: Act and Analysis, above n 3, at EV35.04(2)(a).

39 Stewart $v R$, above $\mathrm{n} 33$, at [63]; Hart $v$ R, above $\mathrm{n}$ 8, at [59].

40 Stewart $v R$, above $n$ 33, at [82]. 
examination may open the door to a previous consistent statement being admitted, but it could equally prejudice the defendant's case if it was not explored (a concern abated by the party's crossexamination duties under s 92). The trial judge, in his or her role as gatekeeper of inadmissible evidence faces similar difficulties: the subtleties of the defence strategy that risk influencing the jury have the potential to be missed. ${ }^{41}$ Despite this, the trial judge is in the best position to assess the general effect of the defence on the jury, because he or she has a better appreciation of "the flavour and atmosphere of cross-examination". ${ }^{42}$ Consequently, given their comparatively disadvantaged position, appellate courts have been reluctant to disturb the findings of the trial judge in respect of a relevant challenge. ${ }^{43}$ The two prerequisites to a challenge required by s 35(2) (that the challenge be to the witness's accuracy or veracity, and be based on either a previous inconsistent statement or a claim of recent invention) reduce the uncertainty faced by defence counsel by providing sufficient controls to put both counsel and judge on notice of the possibility of a challenge and the consequences of such a challenge.

\section{B A Challenge Based on a Previous Inconsistent Statement}

A challenge based on a witness's statement that is inconsistent with his or her testimony can be avoided if it is alleged that the previous inconsistent statement is being offered to prove its truth, and not to impugn the witness's testimony. ${ }^{44}$ At common law, evidence admitted under the rule against the narrative was admissible only for the purpose of enhancing the consistency of the witness and his or her testimony. ${ }^{45}$ Since its introduction there has been debate as to whether the Act changed this position. ${ }^{46}$ The Supreme Court has now decided that once admitted, evidence can be used for all purposes including proving the truth of its content. ${ }^{47}$ This conclusion is consistent with the intentions of the Law Commission ${ }^{48}$ and the general approach of the Act in avoiding limited use provisions, relying instead on the relevance of the evidence as incorporated in s 7.49

The effect of this decision is that where the defence presents the witness with a previous inconsistent statement, it can be contended that the purpose of doing so was not to create a relevant

\footnotetext{
$41 S v R$, above n 35, at [14], citing Nominal Defendant $v$ Clements (1960) 104 CLR 496 at 479.

42 Hart $v$ R, above n 8, at [58].

43 Ibid.

44 Mahoney and others The Evidence Act 2006: Act and Analysis, above n 3, at EV35.04(3)(b).

$45 \quad R v$ Wilson (2004) 21 CRNZ 418 (CA).

46 See Bernard Robertson "Prior Consistent Statements (an issue going by default)" [2009] NZLJ 347.

47 Hart $v$ R, above n 8, at [54].

48 Law Commission Evidence: Evidence Code and Commentary, above n 20, at 99.

49 Hart $v$ R, above n 8, at [54].
} 
challenge under s 35(2) but simply to prove the truth of the contents of the statement. If admitted simply for this purpose, there will have been no relevant trigger to which the witness's previous consistent statement can be admitted to respond, despite the opposing party gaining the benefit of showing inconsistency in the witness's account of events. The argument does, however, seem somewhat disingenuous, as usually an attempt to prove the truth of a statement will at least implicitly contain scepticism as to the truth of any evidence to the contrary. If it is accepted that contradiction of the witness's testimony in respect of his or her veracity or accuracy will usually amount to a challenge, then it is difficult to see how this loophole can be widely taken advantage of. The alternative basis on which a relevant challenge may be made is a claim of recent invention on the part of the witness.

\section{A Challenge Based on a Claim of Recent Invention}

A claim of recent invention or fabrication is described by the Supreme Court as, "a contrivance later in time than the events in issue". ${ }^{50}$ This reflects the common law position that a previous consistent statement is admissible if it logically meets the claim of fabrication by preceding the point in time at which the witness is purported to have invented the allegations. The Supreme Court has acknowledged that there may be some circumstances under the Act in which a previous statement made after the point of alleged invention may still be of assistance to the jury. ${ }^{51}$ "Recent" therefore refers not necessarily to a point in time close to the alleged offending, nor to a point close in time to the trial, but to the period since the time at which the fabrication is said to have occurred. If made prior to this point then the statement would be effective in rebutting the claim of invention. The deliberate use of the term shows an intention to align the position under the Act with that at common law. There has been no change to the concept of "recent invention" under the Act. ${ }^{52}$ What has been changed by the interpretation of s 35(2) is what evidence is permitted to rebut the claim, and when.

In addition to considerations of the contextual emergence of a challenge and the requirement for its relevant basis, s 35(2) also specifies that a previous consistent statement can be admitted only to the extent that the evidence is necessary to "respond" to that challenge. ${ }^{53}$

\section{D "Responding" to the Challenge}

First, whether the evidence is "necessary" to respond to the challenge is a question of "the overall interests of justice and, in particular, fairness to the witness" 54 in permitting the witness to

\footnotetext{
50 Rongonui $v$, above $\mathrm{n} 5$, at [43].

51 Hart $v$ R, above $\mathrm{n} 8$, at [48] and [50].

52 Ibid at [39].

53 Section 35(2).

54 Hart $v$ R, above n 8, at [60].
} 
restore his or her credibility in light of the relevant challenge. ${ }^{55}$ There may be circumstances where other Crown evidence will be sufficient to meet the challenge, and the prior consistent statement will be inadmissible because it is unnecessary. ${ }^{56}$ Thus, in accordance with the contextual approach, the extent to which the relevant challenge has been properly communicated will be relevant. The preceding words of the section "to the extent that" are relevant to the concept of necessity, as they ensure that what is admitted does not go "beyond what is necessary to respond to the challenge". 57 Ultimately, the concept of necessary extent will primarily involve consideration of ss 7 and $8 .{ }^{58}$

A previous consistent statement will "respond" to a challenge where its contents, taking into account the circumstances of its making, "tend to rebut" the claim at the heart of the challenge. ${ }^{59}$ The logical conclusion of this definition is that the challenge must precede the offering of the previous consistent statement as evidence. It is this limitation that has substantially modified the position at common law, provoking debate and uncertainty with respect to the point in time at which a challenge may be made. The Supreme Court in Rongonui $v R$ sought to clarify and resolve the new concepts in s 35 , with particular focus on when a relevant challenge will be triggered.

\section{RONGONUI v R: ATTEMPTS TO ERODE THE EXCLUSIONARY RULE}

In Rongonui, the defendant was charged with sexual violation and assault with intent to commit rape. At trial, the complainant gave evidence to the effect that, immediately after the assault, she spoke to her friends and "told them what had happened". A preliminary issue was whether the evidence amounted to an assertion in order to meet the definition of "statement" under s 4 (and thus fall within the ambit of s 35(1)). If so, as a previous consistent statement, the evidence was inadmissible without first establishing that the defence had put a challenge in accordance with $\mathrm{s}$ 35(2). This is in contrast to the process at common law under the recent complaint exception, where the evidence would have been automatically admitted as part of the complainant's evidence in chief. The Supreme Court in Rongonui debated whether this new hurdle of a prior challenge makes a difference practically, and whether a result similar to the position under the common law rule of recent complaint could be achieved despite the new legislative limitation. Two methods discussed in the case were limiting the ambit of the exclusionary rule in s 35(1), and employing a wide interpretation of "challenge" under s 35(2) in respect of the time at which it is conveyed.

55 Ibid at [36].

56 Ibid at [60]; Singh $v R$ [2010] NZSC 161, [2011] 2 NZLR 322 at [55]; see also Grace $v$ R [2011] NZCA 590 at [32]-[35].

57 Hart $v$ R, above n 8, at [57]; contrast Bernard Robertson "Prior Consistent Statements (an issue going by default)", above n 47 , at 347 .

58 Mahoney and others The Evidence Act 2006: Act and Analysis, above n 3, at EV35.04(5).

59 Hart $v R$, above n 8, at [50]-[51]. 


\section{A Evading the Exclusionary Rule: Limiting the Ambit of $s$ 35(1)}

The majority held that the evidence that the complainant told her friends "what had happened" fell squarely within the scope of the wording of s 35(1): in context the evidence amounted to an assertion that the complainant had been sexually violated by the defendant, thus meeting the definition of statement under s 4 , and the preconditions of s 35(1). ${ }^{60}$

Remarkably, the Court of Appeal has since reached the opposite conclusion on largely similar facts. In $O^{\prime}$ Donnell $v R$ the evidence at issue was that when the complainant arrived home from a party at which she had allegedly been raped, she had spoken to her father. ${ }^{61}$ The Court held this was merely evidence of the fact that the complainant had spoken to someone, and was not assertive of her allegations of rape. ${ }^{62}$ The conclusion is difficult to accept given that the direct result of the conversation was to trigger the father's confrontation with the accused on allegations of rape. Such a direct result gives rise to an irresistible inference that the substance of the complainant's conversation with her father was in the nature of a complaint. The refusal to acknowledge that this irresistible inference amounted to an intention to assert for the purposes of triggering the operation of s 35(1) is plainly inconsistent with the binding majority judgment in Rongonui and the case law on the meaning of "statement". 63

The principal reasoning behind the Chief Justice's dissent in Rongonui was that, on the facts of the case, the evidence that the complainant had told her friends "what had happened" fell outside of the policy rationales behind s 35(1), and thus did not even amount to a prior consistent statement. ${ }^{64}$ According to the Chief Justice, where evidence that would otherwise be a previous consistent statement is also "relevant to prove directly a fact in issue",65 it gains relevance beyond the policy of exclusion to warrant its admissibility without being first subject to the specific admissibility rule in $\mathrm{s}$ 35(1). There are several problems with this reasoning that make it untenable.

The first problem lies in the meaning of "statement" under s 4. Despite the broad definition, Elias CJ reasoned that the evidence fell outside of the meaning of "statement" because it was not an assertion but simply "conduct relevant to the events in issue". ${ }^{66}$ Yet the conduct of the complainant

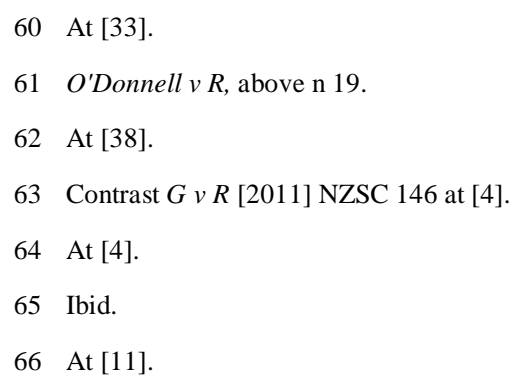


cannot be regarded as anything other than assertive of not only the fact that the complainant had spoken to her friends about the assault, but that the assault occurred in the first place. ${ }^{67}$

It seems her Honour was attempting to create a new exception to the exclusionary rule with the effect of eradicating the distinction between assertive and non-assertive conduct (through which evidence of the fact of complaint can be legitimately admitted, but any reference to substance invokes scrutiny and potential exclusion of the complaint under s 35 (1)). On the evidence in question however, this distinction is not only immensely difficult to draw (as it is not clear at which point the Chief Justice would regard the "substance" of the complaint as being offered), but cannot be supported by the Act's definition of "statement". Whilst considered artificial, the distinction that the complainant may give evidence of the fact of a conversation (lacking in assertion) but is not permitted to add "I told them what had happened" is most certainly favourable to the imprecise and more complicated distinction espoused by the Chief Justice. ${ }^{68}$

The second difficulty is how evidence of a prior complaint proves "directly" the fact in issue of whether the sex was consensual. If one takes the view that evidence that the complainant called her friends and "told them what had happened" is directly relevant or nearly equivalent to her contention of non-consensual sex, then it must inevitably be conceded that the evidence is assertive of this, creating a somewhat circular argument. If however, this is not the intended interpretation, then it is difficult to see the how a "direct" link between the prior complaint and the issue of non-consensual sexual activity can be forged. The link is more of an indirect one, appropriately regulated by a specific admissibility rule.

Lastly, it is not clear how the exception for evidence "relevant to prove directly a fact in issue" could be produced under the wording of s 35(1), which explicitly refers to subss (2) and (3) as the only exceptions to the exclusionary rule. It is further unclear how far the exception would extend. Given that a defence of consent or fabrication will be a fact in issue in the majority of sexual cases, it can be assumed that the policy behind s 35(1) would be held not to apply in such cases. This would permit evidence of a prior complaint to be admitted during a complainant's evidence in chief in order to meet a challenge contained in the mere fact of the defence case. This produces a result remarkably similar to the common law recent complaint exception.

The benefit of arriving at the same result as would have been reached prior to the Act is that the outdated restrictions on common law recent complaint evidence would no longer apply. Thus the complaint would not be restricted by having to have been made at the first reasonable opportunity (a rule that perpetuated the myth that delayed complaints are inherently unreliable or fabricated), ${ }^{69}$ nor

67 At [33].

68 At [13].

69 Compare s 127, which permits the judge to inform the jury that there can be "good reasons" for a delay in making or the failure to make a complaint. 
would the exception apply only to complaints in sexual cases. These benefits are, however, outweighed by the consequence that the creation of a broad exception to the exclusionary rule that applies in all sexual cases eradicates the need for the exclusionary rule in the first place, as most cases arising under s 35 are indeed sexual cases. While it may be said that the policy behind s 35(1) has less relevance in sexual cases where it is less conceivable (though not implausible) that parties will accumulate bundles of "dossiers" of repetitive evidence, ${ }^{70}$ the creation of the exception would be contrary to the express intentions of the Law Commission in rejecting codification of the recent complaint rule. ${ }^{71}$

The imposition of limited ambit of s 35(1), particularly in respect of recent complaint evidence, cannot be supported on the wording and purpose of the Act. However, recent complaint evidence may still be admissible during a witness's evidence in chief where it responds to a challenge made prior to the witness testifying. This route requires a widening of the contextual approach to a challenge.

\section{$B$ Evading the Exclusionary Rule: Expanding the Timing and Incidence of a Relevant Challenge}

The majority in Rongonui $v R$ considered that the usual way for a previous consistent statement to be admitted will be during the witness's re-examination, in response to a challenge to the witness's veracity or accuracy made during his or her cross-examination. ${ }^{72}$ The concession that the required challenge may "become apparent in a sufficiently clear way before the trial or during counsel's opening address"73 has, however, ignited discussion about whether and when evidence of a previous consistent statement should be admitted as part of the witness's evidence in chief. In the view of the majority, Rongonui was not one of these rare cases as their Honours did not find a challenge to which the previous consistent statement could respond, ${ }^{74}$ the consequence being that the evidence had been admitted in error.

In contrast, the Chief Justice maintained that it would be standard for evidence of a previous consistent statement to be admitted during evidence in chief, as a result of a challenge typically materialising prior to this point. ${ }^{75}$ Rongonui, Elias CJ considered, provided a clear example of a pretrial challenge simply through confirmation that the defence was that the sexual activity had been

70 EW Thomas "The Evidence Act 2006 and women" [2008] NZLJ 169 at 171.

71 Law Commission Evidence: Evidence Code and Commentary, above n 20, at 99.

72 At [43].

73 At [44].

74 At [38].

75 At [4]. 
consensual. ${ }^{76}$ In the opinion of the Chief Justice, the defence of consent carries the inherent assertion that the complainant has lied in respect of the allegations forming the basis for the charges, resulting in a challenge to his or her veracity on the basis of recent invention, to which the previous consistent statement was admitted in response. This is also true of a defence that the events in question never happened or have been elaborated upon (a defence of fabrication).

The issue in respect of the timing of a challenge as encountered by the Supreme Court in Rongonui has twice since been before the Court, in two separate cases: $R v B^{77}$ and $B v R .^{78}$ It was also considered, albeit indirectly, in the case of Singh $v R \cdot{ }^{79}$ I will now analyse the implications of these decisions with respect to challenges made at different points during the trial process, and the consequent times at which the evidence of a prior consistent statement may be offered.

\section{TIMING: WHEN CAN A RELEVANT CHALLENGE BE IDENTIFIED?}

The various opportunities during the trial process for a relevant challenge to be identified are:

(1) during pre-trial investigations;

(2) from the nature of the defence case;

(3) during counsel's opening address;

(4) during the cross-examination of a hostile witness;

(5) during the cross-examination of the witness.

\section{A Pre-trial Investigations and the "Risk" Approach}

In $R \vee B$ the defendant was charged with indecent assault of a child. During a police investigation prior to charges being laid, the defendant denied any contact with the child that went beyond cuddling. He claimed instead that if the allegations were indeed true, the complainant could have been expected to complain to her mother or somebody else prior to notification of police by a member of the public. ${ }^{80}$ The Crown wanted to offer, as part of the complainant's evidence in chief, evidence of a prior complaint made to a friend on the basis that it would meet the relevant challenge contained in the defendant's police interview. The Supreme Court found that it was "highly likely, to the point of being practically certain" that the defendant would have put forward a challenge to the

\footnotetext{
76 Ibid.

$77 \quad R \vee B$, above $\mathrm{n} 37$.

$78 \quad B \vee R$ [2011] NZSC 9.

79 Singh $v$ R, above $\mathrm{n} 58$.

80 See s 127.
} 
complainant's veracity based on a claim of recent invention, to which the evidence of the prior complaint would respond. ${ }^{81}$ This conclusion was reached on the basis that the defendant's police interview containing the objection to the allegations was to be offered as Crown evidence (and thus could legitimately precede the witness's testimony) and that it was conceded by defence counsel that the defence would be that the complainant had fabricated the allegations. ${ }^{82}$

While setting an extremely high and prudent threshold for identification of a relevant challenge, the approach based simply on the risk of a challenge eventuating is inappropriate and inconsistent with both the wording of s 35(2) and the contextual assessment of a challenge. The "risk" approach permits the risk of a challenge to be a sufficient trigger for the admission of a previous consistent statement, yet, as noted above at $\mathrm{D},{ }^{83}$ the adoption of "respond" means the section anticipates that the challenge must actually be put before the jury and not merely foreshadowed. While it cannot be disputed that the risk of a challenge was indeed high, it does not alter the fact that it had yet to eventuate before the eyes of the jury, thus departing without good reason from the contextual approach.

The approach of the Court in $R v B$ has now modified the position in Rongonui to the effect that it is simply the risk of a challenge and not the challenge itself that must "become apparent in a sufficiently clear way before trial" in order to trigger s 35(2). The finding of a relevant challenge under this approach means a previous consistent statement would almost invariably be admitted during the witness's evidence in chief in response. The decision was undoubtedly influenced by the procedural difficulties that result from the finding of a challenge at a later point in the trial process. For example, where a challenge is identified during the witness's cross-examination the previous consistent statement will be offered during his or her re-examination. Subsequent cross-examination on the statement by opposing counsel (and indeed, further re-re-examination by the party calling the witness) would require permission from the judge pursuant to s 97(2), amounting to what Tipping $\mathrm{J}$ has described as "a rather untidy process". ${ }^{84}$

\section{$B$ The Nature of the Defence Case: Consent and Fabrication}

\section{Rongonui v R: What is the preferred significance to be ascribed to the defence case?}

In $R v B$, the pre-trial concession of the nature of the defence to be run was seen merely as a contributing factor to determining the likelihood of a challenge being presented. In Rongonui, however, Elias CJ ventured that where a defence of consent is apparent it will amount to a claim of

$81 R \vee B$, above n 37, at [14].

82 At [12].

83 See above in this paper section D, "Responding" to the Challenge.

84 Rongonui $v R$, above $\mathrm{n} 5$, at [44]. 
recent invention. ${ }^{85}$ Though this will very often be the case, ${ }^{86}$ it cannot be said that a defence of consent automatically equates with a claim of recent invention, thereby creating a challenge. In the event that the defendant argues he had reasonable belief in the complainant's consent, he will not necessarily be challenging either the complainant's accuracy or veracity on the basis of recent invention. The majority in Rongonui saw the nature of the defence as being relevant to the extent that the prior consistent statement was necessary to respond, and not as amounting to a relevant challenge in itself. ${ }^{87}$ This is entirely consistent with the contextual approach and represents the preferred weight to be afforded to the mere confirmation of the nature of the defence case. It further avoids both the unsatisfactory "risk" approach adopted in $R v B$ and the even broader approach of Elias CJ.

\section{B v R: An uncertain future for the risk approach}

In $B v R$ the defendant was charged with raping his granddaughter. He denied the charges, the defence being that there was no sexual activity between him and the complainant. Without objection from the defendant, the complainant's evidence in chief at trial comprised a pre-recorded video interview, in which she gave details of separate prior complaints to her grandmothers, $\mathrm{AB}$ and NB. At trial, $\mathrm{AB}$ gave evidence for the defence, implying that the complainant later conceded to her that the complaint was fabricated. In considering the exception opened up by Rongonui, the Court of Appeal concluded that there was a "very high" risk that s 35(2) would be engaged on the basis of recent invention. ${ }^{88}$ This was due to a combination of the defendant's denial of any sexual activity occurring and implicit refutation of the allegations on which the charges were based; ${ }^{89}$ the fact that there had not previously been any objection to the interview being played as the complainant's evidence in chief; 90 and the procedural awkwardness and unfairness that could result from the required "substantial editing" of the complainant's video evidence. ${ }^{91}$

On appeal, the Supreme Court dealt with different arguments as to the admissibility of the evidence (crucially, the objection to the admissibility of the prior complaint to $A B$ was not pursued), ${ }^{92}$ and so did not specifically endorse the conclusion of the Court of Appeal. Despite its subsequent adoption of the "risk" approach in $R v B$, the Court has yet to have the opportunity to

85 Ibid at [4], [5] and [15]; Hart $v$ R, above $\mathrm{n}$ 8, at [19].

86 EW Thomas "The Evidence Act 2006 and women", above n 73, at 171.

87 At [43].

$88 B v R$ [2010] NZCA 493 at [16].

89 At [17].

90 Ibid.

91 At [15].

$92 B v R$, above $\mathrm{n} 81$, at [6]. 
properly assess the appropriateness and implications of the approach. According to the Supreme Court, the evidence of the complainant's concession amounted to a challenge to the complainant's veracity based on recent invention separate from the defence case, ${ }^{93}$ though it ought to be noted this is an example of a challenge that could also be based on the previous inconsistent statement of the complainant. With the objection to the admissibility of the prior complaint to $\mathrm{AB}$ abandoned, the Court considered that the prior complaint to NB was admissible to meet the challenge contained in AB's evidence. $^{94}$

The problem with the reasoning of the Supreme Court in $B v R$ is that it ignores the requirement of $s$ 35(2) that the evidence of a previous consistent statement be admitted to respond to the challenge. As the evidence of a prior complaint was given during the Crown witness's evidence in chief, it preceded the challenge contained in the defence witness's evidence in chief. This is plainly inconsistent with the wording of s 35(2). The more appropriate conclusion is that the evidence of prior complaint to NB was improperly admitted, but failed to result in any prejudice to the defendant as the evidence would have still been before the jury. ${ }^{95}$ Following the challenge contained in AB's testimony, the Crown would have been permitted to recall NB or the complainant to give evidence of her prior complaint pursuant to s 99. This course would certainly prolong the proceedings, as the witness's second testimony would be followed by cross-examination and re-examination on the evidence. ${ }^{96}$

The decision to dismiss the defendant's appeal was therefore influenced by the "rather untidy process" that would ensue as a consequence of the strict application of s 35(2). ${ }^{97}$ Although the outcome is arguably incorrect in that it does not comply with the sequence required by the wording of the section, the consequence of the decision is practically unproblematic.

\title{
C Counsel's Opening Address
}

Using the contextual approach it is possible to foresee instances where counsel will introduce a relevant challenge during their opening address, or even contain their challenge primarily to their opening address (for example, where the line of argument is later abandoned). However, given that the majority in Rongonui considered a challenge led at any point prior to a witness's evidence in chief would be an exception to the norm, it is unlikely that anything short of the express phrasing of an allegation or contention in respect of the witness's veracity or accuracy will result in a finding of

\author{
93 At [8]. \\ 94 Ibid. \\ 95 Compare Elia v R [2011] NZCA 381 at [59]-[62]. \\ 96 Section 8(1)(b). \\ 97 Rongonui v $R$, above n 5, at [44].
}


a relevant challenge at this stage in the trial process. Ultimately, however, it is a question of what the judge perceives has been absorbed by the jury, in accordance with the contextual approach.

\section{Cross-examination of a Hostile Witness}

The Act creates an opportunity for the previous consistent statement of a complainant to be offered by the defence. Where a witness is declared hostile pursuant to s $94,{ }^{98}$ the party calling the witness is permitted to ask leading questions of the witness. A leading question means a question that directly or indirectly suggests a particular answer to the question. ${ }^{99}$ As leading questions are a key feature of cross-examination, what would typically be classified as the witness's evidence in chief (being the point in time where he or she begins to testify) is in reality more appropriately described as cross-examination of a hostile witness. As will be seen, cross-examination of a hostile witness presents different issues to the traditional cross-examination of a witness. Above all, permission to cross-examine in this instance creates the opportunity for the party calling the witness to present a relevant challenge under s 35(2), which theoretically enables the opposing party to offer evidence of the witness's previous consistent statement to restore the credibility of his or her testimony.

In Singh, the complainant was declared hostile after she renounced her initial complaints of violence to police. ${ }^{100}$ The Crown was forced to challenge the veracity of its own witness on the bases of both prior inconsistent statements (her prior complaints) and a claim of recent invention (that is, a claim that her evidence of denial was fabricated). With s 35(2) triggered, it was argued that evidence of the complainant's previous statements which were consistent with her testimony (that the assaults never happened) could be offered by the defence in order to meet the Crown challenge. The Supreme Court found the statements inadmissible, on the basis that they were not necessary to respond to the claim of fabrication. ${ }^{101}$

It will be remembered that "necessary extent" is a concept that incorporates considerations of relevance and prejudicial effect. ${ }^{102}$ The key basis for the Court's reasoning concerned the defence's attempt to lead evidence of the prior consistent statements during the defendant's re-examination. To do so would create issues of unfairness to the Crown case in having to apply to the court to further re-examine the defendant, ${ }^{103}$ as well as practical issues in the likely possibility of having to recall

98 Section 4, "hostile".

99 Section 4, "leading question".

100 Singh $v R$, above $\mathrm{n} 58$.

101 At [53]-[55].

102 Sections 7 and 8.

103 Section 97(2). 
the complainant pursuant to s $99 .{ }^{104}$ Furthermore, the previous consistent statements of the complainant post-dated the point of alleged fabrication, making them less effective in rebutting the claim of recent invention. ${ }^{105}$ Lastly, there was already evidence similar to that contained in the prior consistent statements before the jury, so the evidence did not add anything material to the defence case. ${ }^{106}$

Though Singh is a domestic violence case it is conceivable that the exact same issues relating to a hostile witness could arise in sexual cases, especially given that complainants are commonly familiar with their attackers, and thus face similar pressures and apprehension when it comes to the initial complaint. ${ }^{107}$ Even though the Court found the evidence inadmissible, the reasoning was based primarily on the peculiar time at which the previous consistent statements were sought to be offered. The case should therefore not be interpreted as authority for precluding either the possibility of a relevant challenge being identified during cross-examination of a hostile witness, or the ability to offer evidence of a prior consistent statement in response to such a challenge at a later point in the witness's testimony.

A slightly different example that is possible under the Act, although has yet to arise, is where a witness called by the Crown turns hostile and, in his or her testimony, voluntarily attacks the accuracy or veracity of the complainant by accusing him or her of lying, for example. It is likely that this will be a rare case as the effect of a declaration of hostility is to permit the party who called the witness to ask leading questions of him or her. The use of leading questions will afford the hostile witness little opportunity to give substantive responses, let alone construct a relevant challenge. If the defence later adopts the witness's allegations, it is almost certain that this will amount to a challenge. But where this is not the case it must be questioned whether such attacks amount to a challenge based on recent invention, despite being beyond the control and outside of the intentions of both parties.

Of course there is no express requirement that the opposing party be the one to raise a challenge; this is simply the natural course of events, due to the rule that a party is generally unable to crossexamine his own witness. ${ }^{108}$ Hostile witnesses are the exception to this rule, so there is little preventing these situations from amounting to a relevant challenge. ${ }^{109}$ Not only is this conclusion

104 At [53].

105 At [54].

106 At [55].

107 "A Summary of the Crime Victims and Women's Safety Surveys - A Summary of the two Reports" (1996) Ministry of Justice < www.justice.govt.nz $>$.

108 Section 89(1).

109 Section 94. 
consistent with the contextual approach where, from the perspective of the jury, the complainant's veracity or accuracy would have been put in issue; but it is also consistent with the principle behind s 35(2) that, where such a challenge has occurred, the complainant's credibility and reliability should be able to be restored. To hold otherwise would be to allow the defence to bypass s 35(2) by choosing not to cross-examine the witness on the matter, whilst still benefitting from the complainant's undermined credibility and reliability. It would also jeopardise a key purpose of the Act, promoting fairness to parties and witnesses under s 6(c).

\section{E Cross-examination of the Prosecution Witness}

As anticipated by the majority in Rongonui, the witness's cross-examination is the usual point at which a relevant challenge will be identified. This is due to the primary purpose of crossexamination being to ask leading questions of an adverse witness to "test and cast doubt on the accuracy of the evidence in chief given by the witness". ${ }^{110}$ Despite this being the usual way, their Honours' preference is not without difficulty and, as acknowledged by Tipping J, is likely to produce a "rather untidy process". ${ }^{111}$ The Act proposes practical problems in that, where a previous consistent statement is offered during a witness's re-examination to respond to a challenge made during his or her cross-examination, the defendant is required to apply to the court for permission to re-examine the witness on the statement. ${ }^{112}$ While it is unlikely permission would be refused, the piecemeal approach to cross-examination may amount to an unfairly prejudicial effect to the defendant, ${ }^{113}$ and obstruct his entitlement to be able to present an effective defence. ${ }^{114}$

The same untidiness will inevitably be present where a challenge is identified at even later stages in the trial process, for example, where a relevant challenge is put after the witness has left the stand. The witness may need to be recalled to restore the credibility of his or her testimony, ${ }^{115}$ which in turn causes delay to the proceedings. ${ }^{116} \mathrm{~A}$ desire to avoid any kind of this untidy process certainly motivated the Court in the findings of a relevant challenge prior to the witness taking the stand in both $R \vee B$ cases.

The potential consequences of the judgment in Rongonui and subsequent Supreme Court decisions in respect of the timing at which a relevant challenge may be identified highlight the

110 Mahoney and others The Evidence Act 2006: Act and Analysis, above n 3, at EV84.01.

111 Rongonui $v R$, above $\mathrm{n}$ 5, at [44].

112 Section 97(2).

113 Section 6(c). See Tu'uta $v$ R [2011] NZCA 149 at [22].

114 Section 8(2).

115 Section 99(1).

116 Section 8(1)(b) 
difficulties now faced by trial judges when applying s 35. In order to comply with the direction that the laws of evidence be "clear, simple and accessible" reform of s 35 in its current state is necessary.

\section{OPTIONS FOR REFORM OF S 35}

The judgment of the Court of Appeal in Barlien incited numerous suggestions to resolve the apparent shortcomings of s 35. ${ }^{117}$ These included the Rt Hon Sir Edmund Thomas's recommendation of a specific exception to the exclusionary rule applicable to all prior complaint evidence in sexual cases, ${ }^{118}$ together with an enlargement of the judge's ability to warn under s 127 to include that "the judge is empowered to give the jury a full understanding of the reality of reporting in rape cases". ${ }^{119}$ While an extension to s 127 may indeed be a positive amendment, the creation of an exception to the exclusionary rule that applies only to victims in sexual cases is unnecessarily biased: for example, it is difficult to justify the distinction between victims in sexual cases and victims of domestic violence. ${ }^{120}$

The Law Commission also suggested a reform to s 35 to the effect that: ${ }^{121}$

Previous statements (both consistent and inconsistent) will be admissible on the following conditions:

It must be the statement of a witness (who is then available to be cross-examined on it);

It must be relevant and not be unduly prejudicial or needlessly prolong proceedings (the general principles set out in section 7 and 8 of the Act);

It must in addition be substantially helpful in proving or disproving anything that is of consequence to the proceedings; and

It will be inadmissible if the judge is satisfied that the evidence of the statement is likely not to be an accurate account of what was said.

The Law Commission further recommended that counsel be required to give notice of their intention to lead evidence of a previous statement. ${ }^{122}$ The Ministry of Justice has substantially

$117 R v$ Barlien, above $n 13$.

118 "Briefing to the Hon Simon Power, Minister of Justice: Previous consistent statements as evidence in court - section 35 of the Evidence Act 2006 - options for reform" (19 August 2009) ICP-16-11-07 at 4 (Obtained under Official Information Act 1982 Request to the Ministry of Justice).

119 EW Thomas "The Evidence Act 2006 and women", above n 73, at 172.

120 "Briefing to the Minister, 3 July 2009", above n 15, at 4.

121 Letter from the Law Commission to the Ministry of Justice " $R v$ Barlien [2008] NZCA 180 and section 35 of the Evidence Act 2006" (8 July 2009) at 16 (Obtained under Official Information Act 1982 Request to the Ministry of Justice).

122 Ibid. 
adopted the recommendations of the Law Commission, adding only the requirement that "the circumstances relating to the statement provide reasonable assurance that the statement is reliable" in place of consideration (d), and limiting the instances where notice or leave is required for evidence produced during the witness's evidence in chief or re-examination. ${ }^{123}$

A more fundamental difference between the respective approaches of the Law Commission and the Ministry of Justice is that evidence under the Commission's recommendation is prima facie admissible where the conditions are met, whereas under the Ministry's approach the evidence is prima facie inadmissible until the conditions are met. For this reason the approach of the Ministry ought to be adopted over that of the Law Commission, as it better acknowledges the potential for previous consistent statements to overwhelm the courts with "voluminous amounts of repetitive material in order to shore up a witness's consistency". ${ }^{124}$

The recommendations represent a substantial departure from the current position. In abolishing the technical and problematic requirement for a challenge under s 35(2), they have effectively eliminated the complicated issue of when that challenge is said to arise. It would seem that under the approaches of both the Law Commission and the Ministry of Justice, a previous statement can be admitted at any time during the witness's evidence, subject to the party seeking to lead the evidence first giving notice to opposing counsel.

Such a general reform may seem unnecessary under the Act: with ss 7 and 8 providing sufficient controls against admitting repetitive and superfluous evidence (as is currently the case with previous inconsistent statements). Another option for reform would be to abolish the specific admissibility rule entirely. ${ }^{125}$ A key benefit of this reform would be to do away with both the complex definition of "statement", and the need to determine how the evidence of a prior complaint is expected to be "consistent". However, the specific admissibility provision is intended to guide not only the trial judge on the clearly complicated issue of determining admissibility of the evidence, but also the parties when assessing which evidence to offer. To abolish s 35 entirely would make the law relating to evidence of prior consistent statements unpredictable, as ss 7 and 8 leave much discretion to the trial judge.

The concept of "substantial helpfulness" included in the recommendations of the Law Commission and the Ministry is not unfamiliar to the Act. It appears in both s 25 (Admissibility of expert evidence) and s 37 (Veracity rules). In the case of previous statements the "substantial helpfulness" test creates an appropriately high threshold to minimise the risk of parties offering a

123 "Briefing to the Minister, 19 August 2009", above n 121, at 6.

124 Law Commission Evidence: Evidence Code and Commentary, above n 20, at 99.

125 Elisabeth McDonald and Yvette Tinsley "Evidence issues" in Elisabeth McDonald and Yvette Tinsley (eds) From "Real Rape" To Real Justice: Prosecuting Rape in New Zealand (Victoria University Press, Wellington, 2011) 279 at 345-346. 
deluge of repetitious evidence to bolster a witness's consistency, however where (as under the Law Commission's approach) previous statements are prima facie admissible, the threshold is less effective.

The adoption of the threshold test to address the admissibility of prior consistent statements is consistent with the purpose of the Act, ${ }^{126}$ and permanently disposes of the outdated and elusive common law exceptions regarding previous consistent statements such that the concerns of the Court of Appeal in Barlien need not be reiterated. ${ }^{127}$ In respect of evidence formerly captured under the common law recent complaint rule, the Law Commission anticipates that a witness's previous consistent statements "will only be substantially helpful when the witness's credibility is in question, and even then only in some circumstances". ${ }^{128}$ The Ministry of Justice however, is of the view that Parliament could prudently "send a clear message to the courts that the previous statements of sexual complainants should generally meet the 'substantially helpful' test."129

While this suggestion again draws an unnecessary distinction between the victims of sexual cases and other types of witnesses, it does not go so far as to reintroduce the needless distinction of the recent complaint rule. In fact, it allows for a situation not permitted by either the rule against the narrative nor the current s 35: where the evidence of a prior complaint may be simply relevant to the jury for reasons other than assessing the witness's consistency or credibility. However, given that the majority of cases to raise issues under s 35 are indeed sexual cases, the practical effect of the Ministry's recommendation means that it will be commonplace under the proposed s 35 for evidence of a recent complaint to be routinely admissible, whilst doing away with the requirement that the complaint had to have been made at the "first reasonable opportunity".

Another familiar concept contained in the recommendations is that of reliability. ${ }^{130}$ The Ministry's inclusion of the condition that "the circumstances relating to the statement provide reasonable assurance that the statement is reliable" is primarily relevant to the use of the previous statement where the witness is unable to recall its content, as it is currently found in s 35(3). ${ }^{131}$ However it will also address previously held concerns that prior complaint evidence is easily fabricated. The reference to "reasonable assurance" of reliability means that the statement must simply be reliable enough, and not perfectly reliable. ${ }^{132}$

126 Section 6(a).

$127 R v$ Barlien, above n 13, at [64]-[73].

128 " $R$ v Barlien [2008] NZCA 180 and section 35 of the Evidence Act 2006", above n 124, at 18.

129 "Briefing to the Minister, 19 August 2009", above n 121, at 6.

130 See s 18(1)(a).

131 Section 35(3).

132 Mahoney and others The Evidence Act 2006: Act and Analysis, above n 3, at EV18.02. 
The Ministry's proposal recommends that the requirement for leave to admit a previous statement should not apply to evidence elicited in cross-examination. The requirement of notice in this situation may be seen to interfere with the defendant's right to present an effective defence under s $8(2)$ when seeking to cross-examine a witness on a previous inconsistent statement, as the proposed s 35 relates to previous statements that are both consistent and inconsistent. In respect of evidence given during a witness's evidence in chief and re-examination the notice requirement will address concerns over the courts being "inundated" with repetitious evidence; and, in the case of a previous consistent statement, go towards ascertaining how the evidence is expected to be "consistent". ${ }^{133}$ While it may be argued that the Act is still lacking in a definition of "consistent", the proposed reforms of the Commission and the Ministry do away with much of this concern in applying the same rules to all previous statements, whether consistent or inconsistent. However, to settle matters, it could be argued that the proposed reform ought to include a definition of "statement of a witness" to include statements of a future testifier.

\section{CONCLUSION}

The purpose of the Evidence Act 2006 was to codify and simplify New Zealand's disjointed rules of evidence. With respect to the law of prior consistent statements however, the Act becomes overly complex, producing various difficulties. One such difficulty that remains unresolved postRongonui is the application of the definition of "statement" to the rule in s 35 . In accordance with the decision of the majority in Rongonui, evidence of a prior complaint will be assertive of the content of the complaint, thus amounting to a statement under s 4 and bringing the exclusionary rule in s 35(1) into operation. This should also be the case with evidence that the witness simply spoke to someone where there is an irresistible inference that the discussion was in the nature of a complaint. ${ }^{134}$ Nonetheless, evident in the judgments of the Chief Justice in Rongonui and the Court of Appeal in O'Donnell is a reluctance to apply the provisions in a way that departs from the common law recent complaint exception. This is despite the clear wording of the Act and intentions of the Law Commission. ${ }^{135}$

A larger difficulty lies in the exception to the rule that evidence of a witness's prior consistent statement can be admitted, but only to respond to a relevant challenge. Though the meaning and characteristics of a challenge are now settled under the contextual approach, the exact point at which a challenge may be identified in order to justify the admission of the prior statement in response is still vague. The decision of the majority in Rongonui that a challenge may be triggered prior to the witness being cross-examined has left much scope for uncertainty and departure from the established contextual approach to determining a challenge. Significantly, the application of the

\footnotetext{
133 See above in this paper section II, Section 35(1): The Exclusionary Rule.

134 Rongonui $v R$, above $\mathrm{n}$ 5, at [36].
}

135 See above in this paper section A, Evading the Exclusionary Rule: Limiting the Ambit of s 35(1). 
decision in Rongonui in $R v B$ has produced the unsatisfactory outcome whereby the mere risk of a challenge is now sufficient to open the door to what would otherwise be inadmissible evidence.

After an assessment of the different stages of the trial process at which a relevant challenge can conceivably become sufficiently apparent, it is clear that the results of the procedurally complex requirement are too unpredictable and reform is needed. The impending Law Commission report reviewing the operation of the Act is likely to recommend that the carefully considered proposal of the Ministry of Justice (based on that of the Law Commission) be adopted. This is a desirable outcome as the Ministry's recommendations recognise the importance of the policy behind the exclusionary rule (avoiding a deluge of repetitious and superfluous evidence) with the implementation of the precondition that the evidence must simply be "substantially helpful" to be admitted, yet remove the troubled concept of a "challenge" to dramatically simplify the current law and bring it into line with the purpose of the Act. 